\title{
8
}
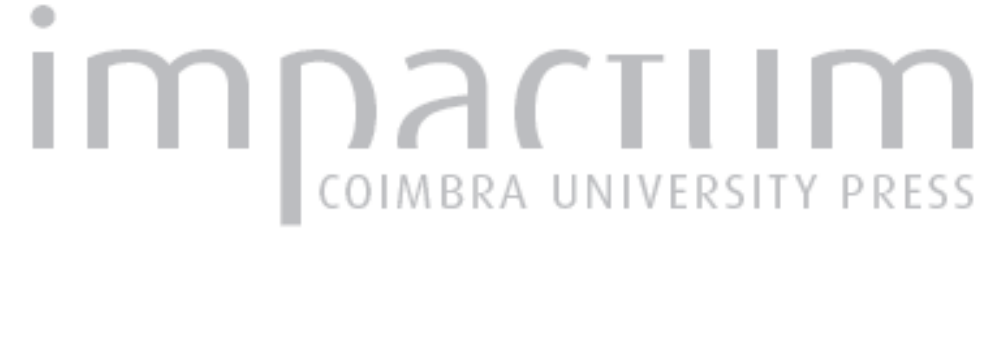

Risorgimento, insorgimento, Antero: (ingressos à felicitação a Umberto de Itália, 1862)

Autor(es): $\quad$ Carvalho, Paulo Archer de

Publicado por: Imprensa da Universidade de Coimbra

URL persistente:

URI:http://hdl.handle.net/10316.2/42555

DOI:

DOI:https://doi.org/10.14195/0870-8584_6_12

Accessed : $\quad$ 26-Apr-2023 12:22:00

A navegação consulta e descarregamento dos títulos inseridos nas Bibliotecas Digitais UC Digitalis, UC Pombalina e UC Impactum, pressupõem a aceitação plena e sem reservas dos Termos e Condições de Uso destas Bibliotecas Digitais, disponíveis em https://digitalis.uc.pt/pt-pt/termos.

Conforme exposto nos referidos Termos e Condições de Uso, o descarregamento de títulos de acesso restrito requer uma licença válida de autorização devendo o utilizador aceder ao(s) documento(s) a partir de um endereço de IP da instituição detentora da supramencionada licença.

Ao utilizador é apenas permitido o descarregamento para uso pessoal, pelo que o emprego do(s) título(s) descarregado(s) para outro fim, designadamente comercial, carece de autorização do respetivo autor ou editor da obra.

Na medida em que todas as obras da UC Digitalis se encontram protegidas pelo Código do Direito de Autor e Direitos Conexos e demais legislação aplicável, toda a cópia, parcial ou total, deste documento, nos casos em que é legalmente admitida, deverá conter ou fazer-se acompanhar por este aviso.

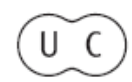




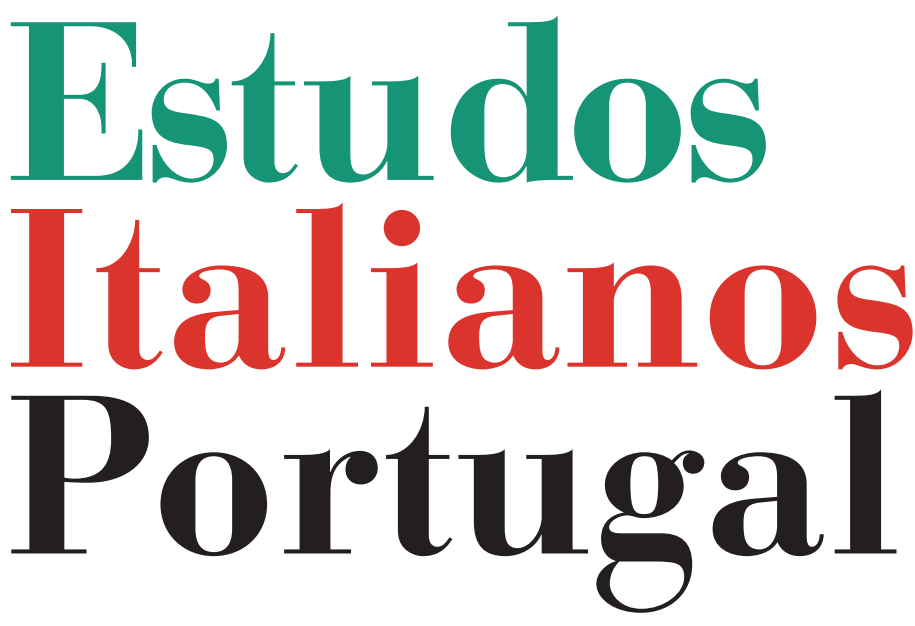

Instituto

Italiano

de Cultura

de Lisboa

Nova Série

$\mathrm{N}^{\circ} 6$ 


\title{
RISORGIMENTO, INSORGIMENTO, ANTERO (INGRES- SOS À FELICITAÇÃO A UMBERTO DE ITÁLIA, 1862)
}

\author{
Paulo Archer de Carvalho*
}

RISORGIMENTO
O céu de Itália!...
esse céu tem, por sol, a liberdade!
Antero de Quental, À Itália (1862)

Victor Hugo na assembleia nacional francesa, em 1848, exigira a dissolução dos partidos políticos e a criação de partidos sociais. Mas os malogros da II República às mãos do presidente-rei Napoleão III, das Repúblicas Romana (de Mazzini, aclamada em Fevereiro de 1849), Toscana (de Guerrazzi e Montanelli), da insurreição de Praga; a derrota polaca em Posen frente à Prússia; a aniquilação austríaca da revolta húngara de Kossuth; pareciam desdizer Hugo. Esse o paradoxo: como partido social o republicanismo rousseauniano falhara e em versōes distintas trade-unions, a filantropia experimental de Owen em New Lanark ou o Manifesto do Partido Comunista (1847-1848), de Marx e Engels, viam na

* Licenciado em História (1985), mestre em História Contemporânea de Portugal (1993) e doutor em Letras (História da Cultura, 2010) pela Faculdade de Letras da Universidade de Coimbra, pós-doutoramento na área da especialidade (FCTCEIS20), autor de artigos, livros e conferências focando a história das representaçôes contemporâneas e dos intelectuais (ideias, mentalidades, historiografia e movimentos culturais). 
produção ou nas lutas de massas novas formas da mobilização social e política. O desaire da Primavera dos Povos, a vaga revolucionária de 1848-1849, subsumira o rumo republicano da Giovine Europa (1834), gerado no sulco de 1830. Não calara, porém, os sagrados direitos da nacionalidade, elegidos na Norma de Fraternidade do movimento.

Giuseppe Mazzini, o ideólogo, federando revolucionários e carbonários na Giovine Italia (1831), clubes jacobinos genoveses, napolitanos (Lomo, Romo), do Véneto, pactuando com Filippo Buonarroti, cria o paradigma teórico e prático dos congéneres movimentos de armas e letras que integram universitários e alguns mestres atentos às culturas nacionais, se não são eles a sua alma. Jovens Checos de Placky, Jovem Polónia de Mickiewicz, Jovens Alemanha, Escandinávia, Suiça, França, firmam o nacionalismo internacionalista mazziniano, republicano, laico. Jovens Turcos (após a guerra da Crimeia), dos quais Kemal Ataturk será legatário, minam a política religiosa otomana confrontada com guerras e separatismos. E, travado o imperialismo da Rússia na Europa, a potência eurasiática expandindo-se a oriente emancipará os servos (1861). À margem, na década de 1840 a Jovem Irlanda antibritânica congrega guerrilheiros republicanos e católicos, base do Sinn Fein, clube dos Fenianos, da Confraria Republicana Irlandesa e do seu braço armado (IRA).

A santa aliança dos "Povos livres na terra / e em peitos novos" convoca a fonte da Grande Revolução e a luta mais próxima da autonomia Grega (segura em 1829 em Adrianópolis), mítica referência da esquerda liberal europeia, em Byron litania da Hélade e do berço da civilização e liberdade - e em Antero (Saudades Pagãs ${ }^{2}, 1863$, cotejadas com a poesia de Giosuè Carducci),

\footnotetext{
${ }^{1}$ Antero de Quental, À Europa [1864], Odes modernas, Porto, Chardron, 1898, 3. ${ }^{\mathrm{a}}$ ed., p. 157.

${ }^{2}$ Primaveras românticas; cf. Maria Helena da Rocha Pereira, "O legado clássico em Antero de Quental”, Colóquio. Letras, 123-124, Antero, 1992, pp. 13-25.
} 
[...] a cidade ideal! a Lei eterna,

banhava-a sempre uma aurora imensa, quando um povo de deuses, radiante

de mocidade e brilho, caminhava [...]

Luta forjada na Philiké Hatairía, confraria secreta que agrega desenraizados, intelectuais, non garantiti, carbonários ou condottieiri, à burguesia ávida de desfeudalizar fortunas, à semelhança do poente continental. No Sul, o grés das revoltas primárias contra a retraída industrialização acha resistências em imaginários envelhecidos, rurais, analfabetos (Kedurie, Tom Nairn). A kantiana autodeterminação, racional guia da razão prática e do livre agir, com Herder e a metafísica social dos discursos nacionalistas, toma a nação como "base natural" da pólis ${ }^{3}$, relativização política do universal abstracto das Luzes. E dá mediaçôes sociais e linguísticas à lenta dessacralização das sociedades arcaicas (Weber) e à correlata sacralização da instância política nas novas sociedades (Durkheim) que, no corso histórico, operam conflituais "deslocamentos da sacralidade" (Chartier), sem os quais é inatendível a contemporânea apreensão (ainda) eurocêntrica do mundo.

A questão das nacionalidades solicita representações da Kultur, que nas várias filologias é termo erudito e elitista, Aufklärer, agora em uso nos intelectuais liberais. Leito da arcana cultura à cata do tecto político ${ }^{4}$, a Itália será o topos para a geração romântica e revolucionária gizar a libertação dos povos na extensa arqueologia do Antigo regime europeu. Relembre-se que a opinião pública liberal se mobiliza no atentado patriótico e condenação de Felice Orsini contra Napoléon-le-Petit em 1858, na Ópera de Paris; nos passos múltiplos da libertação italiana, conduzida pelos camisas vermelhas de Garibaldi, o militante revolucionário, herói

\footnotetext{
${ }^{3}$ Ernest Gellner, Dos nacionalismos, Lisboa, Teorema, 1994, pp. 78; 77-92.

${ }^{4}$ Cf. id., Naçôes e nacionalismo, Lisboa, Gradiva, 1993, pp. 133-162.
} 
de dois mundos e da Marcha dos mil na II libertação; ou no massacre de Perugia (20 de Junho de 1859) pelas hostes pontifícias de Schmidt, agraciado pelo Papa.

Cindido o ultramontanismo dominante pela consciência liberal, as mentalidades católicas são presa de dois mundos, o de um passado que a queda de Metternich e o ascenso do exorcismo anti-racionalista não fechara (na locução de Pio IX, Maxima quidem, 1862, anúncio da Quanta Cura e do Syllabus), e o de um presente, o do século da ciência, da liberdade e da revolução social, ao qual conceptualmente não se abria ${ }^{5}$.

\section{Claridades do Sul}

Coimbra, outubro de 1862. Lê-se num jornal, "Acha-se depositado na mão de Francisco Maria Martins, ourives, morador na rua Visconde da Luz, um vaso de Sacrário, de prata. Quem se julgar com direito a ele, poderá reclamá-lo dando provas necessárias de que lhe pertence" ${ }^{\text {. }}$. Promulgara-se nesse ano nova legislação anticongreganista que cerrava as portas dos conventos, premida pela questão das Irmãs de caridade. A amnistia para crimes políticos fora assinada por Loulé, liberalidade em honra de Luís, novo rei desde 14 de outubro de 1861.

Neto de Carlo Alberto, o rei constitucional exilado no Porto, filho de Vittorio Emanuele II, o piemontês unificador da Itália (então ainda sem Roma, os territórios pontifícios e o

${ }^{5}$ Cf. A. D. Smith, La identidad nacional, Madrid, Trama, 1997; E. J. Hobsbwam, A era das revoluçôes. 1789-1848, Lisboa, Presença, 1982, 2. a ed., pp. 153-99; id., A questão do nacionalismo. Naçôes e nacionalismo desde 1780, Lisboa, Terramar, 1998, pp. 19-46; Ernest Gellner, Naçôes e nacionalismos; M. L. Salvadori (ed.), História Universal, s. 1., De Agostini, 2005, XII, "Napoleão e a Restauração. Os movimentos político-sociais do século XIX”, pp. 252-262, 557-568; XIII “As unificações nacionais na Europa [...]", pp. 15-99; Maria Manuela Tavares Ribeiro, Portugal e a Revolução de 1848, Coimbra, Minerva, 1990.

${ }^{6}$ O Conimbricense, n. ${ }^{\circ} 911$, 21-10-1862. Itálico meu. 
Véneto), Umberto ${ }^{7}$ em visita de Estado vem à cidade. A irmã, Maria Pia de Sabóia (1847-1911), ratificara o casamento a 6 de outubro com D. Luís (1838-1889). O diplomata em Turim, Borges de Castro, volta à rotina dos relatos políticos e militares da guerra e paz, após a azáfama das listas infindáveis de condecorações, comendas e colares a distribuir pela Itália das famílias e acertos no protocolo matrimonial e patrimonial ${ }^{8}$.

O pacto das coroas insufla o suão liberal nas duas penínsulas. A política externa de Cavour (1810-1861), depois seguida, casa-se bem com a aliança diplomática, sob suspeição da Espanha dos Bourbons (o revés das Duas Sicílias) ${ }^{9}$ e estratégico patrocínio da Grã-Bretanha vitoriana e vitoriosa. No plano interno, o governo italiano, com Ricasoli e depois Rattazzi, opta pela discreta pressão sobre o papado na renovação do catolicismo (Igreja livre num Estado livre) ${ }^{10}$, inspirada pelo Gioberti da Renovação, acordando Vittorio Emanuele e Napoleão e, como se verá em Mentana (1867), trava os anticlericais comitati di provvedimento de Garibaldi (Estado livre da Igreja), aquietando a Igreja livre do Estado, não ferindo o que resta do seu poder temporal. Após dois séculos inférteis de núpcias políticas na aliança Habsburgo, Rei, governo e Estado português casam com a ex-súbdita do ex-aliado. Abona a reminiscência da segunda pátria, o consolo "che il Portogallo aveva concesso agli ultimi giorni dolorosi di Carlo

\footnotetext{
${ }^{7}$ Umberto (nascido em 1844) fora promovido, a 11 de outubro, chefe da brigada de granadeiros da Lombardia. Foi Rei de Itália em 1878, por morte de Vittorio Emanuele II, e morreu às mãos do anarquista Gaetano Bresci, em 1900, no acume da acção directa que visava as cabeças coroadas da Europa e o "poder burguês".

${ }^{8}$ Cf. documentação publicada por Eduardo Brazão, "A unificação da Itália vista pelos diplomatas portugueses. 1848-1870”, Biblos, 37, 1961, e 38, 1962.

${ }^{9}$ Relatará o embaixador espanhol em Lisboa: "não há aqui nenhum dos elementos que se reuniram no Piemonte" e "possam influir nos destinos da Espanha”, cit. por Oliveira Martins, Portugal contemporâneo, II, Mem Martins, Europa-América, 1986, p. 277.

${ }^{10}$ Cf. A. [Auguste] Vera, Cavour e libera Chiesa in libero Stato, Napoli, Stamperia della R. Università, 1871.
} 
Alberto" ${ }^{11}$. Por cá, é aura de esperança para o patuleia Martins de Carvalho, de "paz e quietação para todos os que têm sido vítimas do sistema adoptado pelo actual ministério"12. Rei dos que auferem benesses, títulos, altos cargos do Estado, funcionalismo e bacharéis que a eles aspiram, era-o menos da massa dos camponeses sem escola e com fé no Trono e no Altar, cuja representação política (não-cidadãos, na teoria social e prática eleitoral) pouco se alterara desde 1834 ou 1847. A indústria urbana do Norte europeu não esfuma o agro meridional, "Ares tão puros, raios de sol brilhantes / com tudo isto à beira do imenso mar"13. Mas "poucos países há em que a agricultura esteja tão atrasada" ${ }^{14}$. Anos raros de trabalho, melhoramentos materiais, paz civil, santa Liberdade, não iludem que o descontrolo que a dívida pública e o défice sofrem, desde c. 1800, são o instável fiel da ilusória autonomia.

Os sopas, regeneradores ordeiristas, liderados por Sant'Ana Correia, felicitam D. Luís em nome dos "cordiais sentimentos" académicos e evocam "todas essas épocas de maior glória [...] em que os nossos, dominando os mares, batiam com os escudos à porta do Oriente, para aí hastearem as quinas de Portugal". Se Maria Pia é "o mais seguro sustentáculo da verdadeira civilização e liberdade", garantem "a seu augusto pai, à Itália e ao mundo, que os académicos, uma vez alistados debaixo das bandeiras da liberdade, hão-de aderir em todos os tempos aos sentimentos generosos e magnânimos não só do povo que os viu nascer, mas de todos que tomarem a nossa divisa". A réplica do Rei é a politicamente correcta,

${ }^{11}$ Cf. Eduardo Brazão, "A unificação da Itália vista pelos diplomatas portuguesas. 1848-1870", Biblos, 38, 1962, documentos LI-LVII, ano 1862 varia.

${ }^{12}$ O Conimbricense, n. ${ }^{\circ}$ 909, 11-10-1862, p. 1, cl. 1.

${ }^{13}$ Hans Christian Andersen, Uma visita a Portugal em 1866, Vila Nova de Gaia, Gailivro, 2003, 4. ${ }^{\text {e }}$ d., p. 35.

${ }^{14}$ Maria Ratazzi, na sua polémica obra, Portugal de relance [1876-1879], Lisboa, Antígona, 1997, p. 261. 
"também eu tenho viva fé no futuro, e conto com toda a mocidade estudiosa para realizar as generosas aspirações da nossa época, progredindo nos melhoramentos que a geração presente encetou, e a que nós devemos dar todo o impulso" 15 .

Soldando alianças, o programa coimbrão da visita italiana inclui saraus teatrais, oração de sapientia por Mota Veiga, presumivelmente em latim (que o príncipe confunde com português), visitas, vénias, bodas protocolares, esmolas a pobres ${ }^{16}$. A Academia Dramática, que integra alguns sopas, saúda o "Augusto Filho do Libertador da Itália", exaltando "cada nova vitória que arrancava um povo à escravidão para o abrigar sob a bandeira dos livres", no tom das profecias do passado: "Irmãos pelas tradições gloriosas, irmãos por Colombo e Gama, irmãos por Camões e Tasso, Italianos e Portugueses, eis-nos agora unidos em mais estreita aliança" ${ }^{17}$. Nacionalismo, toada épica e historicismo melhor quadram a ideologia morigeradora do texto ao estilo do velho Il Risorgimento, editado por Camilo Benso e Cesare Balbo (Turim, 1847), adequado ao ordeirismo aristocrático liberal e a Umberto de Sabóia. A prosa careceria ser arrancada à escravidão.

\section{(A Sociedade Do) RaIO DE EXTINTA LUZ}

Sagrado nas folhas estudantis e récitas (na homenagem, maio de 1862, a Castilho), Antero a 21 de outubro lidera o grupo académico que intercepta na ponte a comitiva de Umberto. $\mathrm{O}$ Risorgimento aquece almas aventureiras, radicais

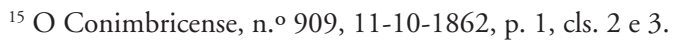

${ }^{16}$ Mário Brandão, "Antero de Quental estudante. Documentos", Boletim da Biblioteca da Universidade de Coimbra, 23, 1957, com extensas notas; José Bernardino, "Anthero de Quental e o príncipe Humberto (uma rectificação)", Nova Alvorada, I, n. ${ }^{\circ}$ 11, 1-3-1892 [Vila Nova de Famalicão], pp. 105-106, Luís R. H. R. Jardim, Visita do príncipe Humberto de Sabóia a Coimbra em outubro de 1862, Angra do Heroísmo, IHIT, 1981; José Bruno Carreiro, Antero de Quental. Subsidios para uma biografia, Braga, ICPD/Pax, I, 1981, 2. ${ }^{\mathrm{a}}$ ed., pp. 179-182.

${ }^{17}$ O Conimbricense, n. ${ }^{\circ} 912,25-10-1862$, p. 2, cl. 2. 
liberais, zelosos dessa genealogia moral e pessoal da luta pela liberdade. No seu hosana, o poeta lê a liberdade política à luz da libertação religiosa e da fraternidade entre os dois povos, "não é ao representante da Casa de Sabóia que vimos prestar homenagem; é ao filho do Primeiro Soldado da Independência Italiana, desse, de quem os reis da Europa aprendem como neste século ainda se pode ser popular sendo-se rei; de quem a Itália espera ressurreição completa; de quem espera a igreja cristã uma nova época de verdadeira grandeza, e liberdade verdadeira". O "coração da Itália, que o é também o do mundo cristão", une-se "à pátria de Garibaldi" a reaver "o sagrado património da sua nacionalidade"18.

O Conimbricense, do carbonário de 1848, Martins de Carvalho, omite "ao filho do amigo de Garibaldi", citado noutras versōes do mesmo texto ${ }^{19}$. Dito não escrito, dúvida sobre a ocasião, dada a derrota da esquerda e o perdão de Vittorio Emanuele, seria debatido no colectivo que assina o texto e incumbe Antero de o redigir? É que cinco dos oito subscritores integram a Sociedade do Raio ${ }^{20}$, três dos cinco "chefes de secção" (Antero, José Falcão, José Sampaio, o presidente da Sociedade do Raio). Leia-se o subliminar ataque ao reitor: "À mocidade portuguesa [...] não lhe sofre o espírito, ainda que opresso por um fantasma do passado [aponta para o reitor Basílio Alberto de Sousa Pinto], que não vire os olhos para a banda da luz, onde no meio do combate se enlaça o braço do rei ao braço do povo". No dia seguinte, reforça o insight no poema À Itália: só "um raio de claridade" varrerá a "treva". Qualquer membro da Sociedade do Raio bem julga o que noutros soa metáfora. Mas não é enunciado antimonár-

$18 \mathrm{Ib}$.

${ }^{19}$ Cf. António Nóvoa, "Em nome da Liberdade. Um importante inédito de Antero redigido no âmbito das actividades da 'Sociedade do raio' (1861-1863)" Revista de História das Ideias, 13, 1991, p. 238.

${ }^{20}$ Reconhecem-se Eduardo David (e Cunha) e Mariano Machado (de Faria e Maia), ib., pp. 257-259. 
quico $^{21}$. Se ele, por um lado, se acerca do federalismo republicano, como na calorosa crítica (1860) a Estudos sobre a Reforma em Portugal, de Henriques Nogueira, e do iberismo de 1868, por outro lado, do republicanismo, regime, não da sua mundividência ${ }^{22}$, distancia-se na década seguinte, arguindo a sua insuficiência res publicana e a falha na abordagem à questão social. O que fulgura o texto é o antecipado estrondo do 8 de dezembro na sala dos Capelos e a parede académica. Capitólio constitucional de 1822, o reitor Basílio Alberto de Sousa Pinto tombará. É o triunfo dos inquilinos, sentido icástico mais do que disfórico. A trama urdira-se em casas do bairro propriedade do ex-reitor.

Voam ideias "de independência, de reforma dos regulamentos universitários, de liberdade de ensino" 23 nas asas dos traças, "sociedade organizada de noite", de "ritos maçónicos, juramentos terríveis, fim proveitoso nenhum"24. "Proclamámos uma manhã a libertação da Polónia”, alega Eça a insurreição permanente até à Rolinada (1864), "abandonámos a Universidade, num clamoroso êxodo, para irmos fundar nos arredores do Porto uma civilização mais ou menos em harmonia com o nosso horror aos compêndios". Criador dessa cosmogonia, "vivíamos em espírito e verdade" 25 , Antero juramenta na Sociedade do Raio o derrube do "despotismo das instituições académicas, fontes de desmoralização para nós e para o país". Raízes psicológicas e pessoais do clube, no bra-

${ }^{21}$ Óscar Lopes, Antero de Quental. Vida e legado de uma utopia, Lisboa, Caminho, 1983, p. 123. Cf. o verbete "Antero de Quental”, Dicionário da I República e do Republicanismo (CCCR, no prelo).

${ }^{22}$ Fernando Catroga, Antero de Quental. História, socialismo, política, Lisboa, Notícias, 2001, p. 200.

${ }^{23}$ Joaquim Martins de Carvalho, Apontamentos para a história contemporânea, Coimbra, Imprensa de Universidade, 1868, p. 263.

${ }^{24}$ O Atila, 3, pp. 17-18; cf. Joaquim de Carvalho, "A evolução espiritual de Antero" [1929; 1955], Obra Completa, vol. IV, Lisboa, FCG, 1983, p. 556.

${ }^{25}$ Antero de Quental, Cartas, I, Obras completas, ed. Ana Maria Almeida Martins Lisboa, UA/Comunicação, 1989, p. 4. 
seiro do caso Vieira de Castro, atam-se ao assomo herético e praxístico da Páscoa de 1859 que o leva à prisão académica (e à expulsão por 2 anos de José Sampaio), clamando inocência. Simpliciter jurista aprendiz (chumbara no ano anterior), Antero nutre proudhoniana aversão ao Direito (proibidas as Conferências, em 1871, acusa Ávila: lei, é a opinião armada). $\mathrm{O}$ anacrónico cânone no qual transgressão e norma se fundavam $^{26}$ elucida o combate ideológico aos vícios escolásticos que coartam livre indagação e opinião, desmontados à opinião ilustrada do país. Se alguns correlacionam a carbonária académica, a Maçonaria e o eventual ascendente d'o Filipe sobre o sobrinho ${ }^{27}$, Antero não integrará a loja erguida sobre a Sociedade do Raio em 1863.

O MUNDO ORIGINALÍSSIMO DE AVENTUREIROS E A QUESTÃO ROMANA Ambiente eufórico. A orquestra ataca o hino de Vittorio Emanuele e Fialho Machado recita o poema À Itália, na trilogia Deus-Amor-Liberdade o cume da emoção da liberdade. Escreve Joaquim de Carvalho: "poeticamente a mais antiga manifestação deste sentimento parece estar associada ao entusiasmo pela gesta de Garibaldi e logo se apresentou vestida a moda parenética e oratória que a Liberdade sempre teve no seu estro" ${ }^{29}$.

Itália e Portugal! Que duas pátrias!

Ambas tão belas tão amadas ambas !

Uma a pátria do berço; outra a das almas;

uma a das artes! Outra dos combates!

\footnotetext{
${ }^{26}$ Cf. Joaquim de Carvalho, "A evolução espiritual de Antero", pp. 555-558.

${ }^{27}$ Referente epistolar de Filipe do Quental, então a preparar Actos, integra a genealogia maçónica da família Quental. Oliveira Marques interroga a efectiva filiação de Antero, no Dicionário da Maçonaria portuguesa, Lisboa, Delta, 1986.

${ }^{28}$ Membro da Sociedade do raio, Raimundo Capela regista, "Deu um trabalho para o vestir e escovar, e ensaiá-lo nos modos e cortesias. Antero temia de apavorar-se na presença do príncipe, dos camaristas [...]”, cit. em António José Saraiva, A tertúlia ocidental [...], Lisboa, Gradiva, 1995, 2. ${ }^{\text {a }}$ ed., p. 187.

${ }^{29}$ Joaquim de Carvalho, "A evolução espiritual de Antero", p. 565
} 
Antero é instado à tribuna, mas a comitiva está indignada, Umberto "engoliu em seco" 30, "não respondeu, não sabia que responder. Corou, balbuciou, cochichou com os cortesãos que lhe faziam lados, e acabou por apertar afectuosamente a mão de Antero e dos seus companheiros, os quais com a graça mais familiar do mundo, lhe entregaram a tradução italiana da alocução, a fim de que sua alteza ficasse bem certo de que a Academia de Coimbra o respeitava somente, por constar ser ele o amigo particular do heróico demagogo, ferido em Aspromonte, pelas balas dos soldados do seu real papá" 31 . Os soldados estavam lá. Cialdini ${ }^{32}$ e Pallavicini sorriem ${ }^{33}$. Garibaldi fora amnistiado e solto por Vittorio Emanuele no júbilo pelo casamento da última filha, Maria Pia.

Do "viver quase patriarcal de uma província remota e imersa no seu plácido sono histórico", Antero aproxima-se do vértice daquela "espécie de revolução intelectual e moral"34. O enunciado da saudação inicial é mais límpido, o canto dobra tiradas formais. $O$ vinco parenético notado por Joaquim de Carvalho veste palavras no rito do sacerdos. Falta-lhes, aos versículos (ofício sem simulacro na sua poesia), a espessura filosófica do atravessamento da dor, para serem demasiado humanos,

Se é possível que exista um povo - um povo! sem ser livre, e sem sol o céu da Itália ?!

${ }^{30}$ Teófilo Braga, História da Universidade de Coimbra [...], Lisboa, Academia Real das Ciências, 1902, vol. 4, p. 490.

${ }^{31}$ Raimundo Capela, cit. em António José Saraiva, A tertúlia ocidental [...], p. 188.

${ }^{32}$ General que em Forestali, a 29-8-62, vence Garibaldi. Glória do Risorgimento, após a rendição de Ancona, Enrico Cialdini migra para Paris e em Portugal combate o miguelismo, tendo sido condecorado por D. Pedro IV, e os carlistas em Espanha. Regressado a Itália, por ocasião da II libertação, derrota as tropas pontifícias enquanto Garibaldi toma a Sicília. Participa na queda de Nápoles e chefia a capitulação de Veneza (1866).

${ }^{33}$ José Bruno Carreiro, Antero de Quental. Subsidios para uma biografia, p. 181.

${ }^{34}$ Antero de Quental, Cartas a Wilhelm Storck [1887], Coimbra, Imprensa da Universidade, 1921, 2. ${ }^{\mathrm{a}}$ ed., p. 2. 
Itália é a iconologia libertadora, numa Europa no auge do poder mundial firmado desde o século XVI, que 1918-1945 inverterá. $\mathrm{O}$ custo, sabe-se, a servidão do mundo, mal a intelligentsia paga. O que alicia Antero na Itália, com decepçōes ${ }^{35}$, é certo, e também na Alemanha de Heine e Hegel, nos Estados Unidos da América a reconstruírem-se da guerra civil e a desiludirem-no, na França das terapias e de Proudhon, ou na irmã ibérica, é o espelho contemporâneo da vis do progresso, iluminado pelos exempla dos exilados liberais e pelos exempla da evolução.

Vida e cultura poética italiana (Dante ${ }^{36}$, Leopardi, Manzoni), música ${ }^{37}$, poesia da língua ${ }^{38}$, a estranha atraç̧ão de Roma, aliciam-no. Desafia o amigo, que por sinal era sobrinho de Camilo (e a Alberto para tipógrafo em Paris, no rasto de Michelet e Proudhon), a alistarem-se nos camisas vermelhas. Como no Pensamento e acção de Mazzini, evoca que un bel morir tutta la vita onòra e, acaso, "pudemos estudar, ver, pensar; há bibliotecas em todas as cidades italianas e espero que se encontrem homens...”. Anos depois, ávido da Vita nova de Dante de que tanto carece (após 1872-1874, acentua-se a doença e a falha da vida activa), incita o mais próximo dos manos Albertos ("quantas ilusões nos faltam ainda por perder") a integrar a guarda papal,

\footnotetext{
${ }^{35}$ Refere ao poeta Canizzarro, em 1887, que "todas as nações latinas, como a Itália, se acham na fase funesta para tudo quanto se diz franqueza de carácter e elevação moral", Cartas, 1921, p. 303.

${ }^{36}$ Cf. Amina Di Muno, "Antero de Quental perante a Itália. Alegoria de Beatrice em Dante e na poesia anteriana”, Letras \& Letras, 5, n. 59 [Porto], 20-11-1990, pp. 9-10.

${ }^{37}$ Cf. A Genano Perrelli, artista e patriota, Coimbra, I. V. 1862.

${ }^{38}$ Escreve, em 1887, ao tradutor (além de Teza e Marco Antonio Canini), Tommazzo Canizzarro, elogiando o trabalho "na língua por excelência poética que é o italiano", "Dou-lhe pois os parabéns, e ainda os dou maiores a mim próprio, por ver os meus pobres versos assim revestidos das galas incomparáveis da métrica italiana", Cartas, 1921, p. 319. O autor de Garibaldi e Mazzini (1882) despede-se "In morte di Anthero de Quental”, em Tramonti, Messina, Tipi dell'autore, 1892, pp. 203-207.
} 
[...] único plano resistente e que dura há meses já. Por ser extravagante, nem por isso deixa de ser óptimo. É de ir assentar praça de voluntários nos Zuavos pontifícios. No nosso estado, quando se procura a acção, deve ser uma acção estranha bastante, e nesse género parece-me que escolhi bem. Que humorismo profundo em todos os contrastes de uma tal vida! Ateus a manterem guarda no Vaticano! Socialistas a defenderem o poder temporal do Papa! Que há de mais característico em todas as contradiçôes expressivas do nosso tempo? Depois Roma... e o mundo originalíssimo de aventureiros que há dois anos não cessam, de todos os pontos da Cristandade, de correr para Roma. Espero que haverá no meio deles pelo menos uma dúzia de homens com quem nos agradará viver...

O que te parece isto? Por ora não resolvi nada. Se tivesse resolvido já lá estava. $[\ldots]^{39}$

Porém, vê de mais para poder ser activo ${ }^{40}$. Quer evadir-se para o real, o que não estranha. A carta, do verão de 1868 , surge três anos após Em defesa da Carta Encíclica de S. S. Pio IX contra a chamada opinião liberal (de janeiro de 1865). Sobre o polémico teor do panfleto, ataque radical à Igreja no paradoxo da mediação histórica da ideação do Absoluto, se "o Cristianismo e o mundo actual são inimigos" ${ }^{1}$, releva a retrospectiva, "glorificando o Pontífice pela beleza da sua atitude intransigente em face do século, via nessa intransigência uma lei histórica, rezava respeitosamente um De profundis sobre a igreja condenada pela mesma grandeza da sua instituição a cair inteira mas não a render-se, e atacava a hipocrisia dos jornais liberais" "², situação metalógica que foi a sua em 1862, na saudação a Umberto.

${ }^{39}$ Antero de Quental, Cartas inéditas a Alberto Sampaio, ed. Ana Maria Almeida Martins, Lisboa, O Jornal, 1985, p. 23.

${ }^{40}$ J. P. Oliveira Martins, em Antero de Quental, Sonetos, ed. António Sérgio, Lisboa, Sá da Costa, 1984, 7. a ed., p. LXX.

${ }^{41}$ Maria Fernanda Enes, "O discurso anteriano e a questão laica [...]", Revista de História das Ideias, 13, 1991, pp. 374-375.

${ }^{42}$ Antero de Quental, Cartas, 1921, p. 4. 
Imagina(-se) nas opostas barricadas do conflito romano, que era europeu, com Garibaldi contra o Papa, com o Papa contra Garibaldi, méthys útil para a abstracção dialéctica, mas árdua na raiz do viver. No passo, autores (Joel Serrão, António José Saraiva, Eduardo Lourenço) leram Antero contra Antero, fugindo de si próprio, a cesurar sem refega o princípio da Autoridade e a opinião liberal ${ }^{43}$. Certo. Talvez se leia melhor nessa época a incisão do impulso destrutivo na construtiva razão, Ideia e acracia (nos inícios de 1860, destruo ut oedificabo é o seu lema ${ }^{44}$ ), no sentido proudhoniano de raiz socialista, visto como momento fundador de uma nova antropologia.

Se o apelo à acção imerge na "enfermidade mística" ${ }^{45}$, a reflexão no fundo do lago leva-o à raiz metafísica abstractamente teísta, da qual não se evadira ${ }^{46}$. Questão é saber, antecipando o posterior sentido autocrítico ou auto-irónico, se o originário uso da "ironia transcendental" (nomeou-a Oliveira Martins) é o penser contre lui-même $e^{47}$ do anti-Fradique, ou se é locução antitética, só dirimida na síntese resolutiva. Esse, após sentenciar o proselitismo jesuítico em $A$ Indiferença em política, "é o pleito entre o obscurantismo, a intolerância a e a tirania, universais inimigos do homem, e a ilustração, a tolerância e a liberdade" (A Questão romana) ${ }^{48}$. Em 1862, indaga a reforma da Igreja. Mas os templos são hostis, a rotura ideada é salto no vazio, "nunca chegará a preencher o vazio deixado pela morte de Deus" ${ }^{49}$. Após 1864-1865, aclara-se que o imanente Espírito absoluto não se relativiza ou fixa

${ }^{43}$ António José Saraiva, A tertúlia ocidental [...], 27, pp. 195-199.

${ }^{44}$ R. Capela, cit. ib., p. 188.

${ }^{45}$ Antero de Quental, Cartas, I, 1989, p. 199 [XXIV].

${ }^{46}$ Eduardo Lourenço, A noite intacta. (I)recuperável Antero, Vila do Conde, CEA, 2001, pp. 114-115.

${ }^{47} \mathrm{Ib}$., p. 111.

${ }^{48}$ Antero de Quental, Obras completas, III,1991, pp. 43-51.

${ }^{49}$ Fernando Catroga, Antero de Quental. História, socialismo, política, p. 16. 
cedendo ao tempo. Quer inalar novo absoluto, a igreja da revolução, religião imanente ${ }^{50}$, promessa, "O novo mundo é toda uma alma nova / um homem novo, um Deus desconhecido!" 51 . Por fim, exigida pela inarrável autobiografia do não-devir, advirá a negatividade do tempo, não-ser absoluto, termo da narrativa da qual o relator se ausentou ${ }^{52} \mathrm{Na}$ lição espinosiana, para o filósofo a preservação no ser e o questionamento da morte é uma metafísica da relação com o mundo ${ }^{53}$.

FiLOSOFIAS DO RISORGIMENTO NA HISTORIOSOFIA ANTERIANA Joaquim de Carvalho, ao instar sobre a mediação de Vera (1813-1885) nas leituras hegelianas de Antero (que o próprio indiciava), não relevara o contributo próprio que o filósofo italiano, juntamente com Rémusat e Rosenkranz, grandes comentadores e divulgadores críticos do autor de Fenomenologia do Espirito, dera à filosofia do açoriano. Indagando a via, Catroga credita o alvitre, firmando "o peso da cultura italiana no aprofundamento anteriano das questóes da história, tema que muito preocupou a sua geração, boa parte dela entusiasmada com a experiência do Risorgimento" ${ }^{\text {". }}$. Antero perspectiva a história filosófica e a historiosofia como superação do transcendentalismo kantiano, ao acolher a antítese fichetiana eu/não-eu e a lição do idealismo subjec-

50 Antero de Quental, A Bíblia da Humanidade de Michelet; cf. António Sérgio, Ensaios, Lisboa, Sá da Costa, vol. IV, 1972, p. 171.

51 Antero de Quental, “Secol' si rinuova”, VIII, Odes modernas, p. 104.

52 No último ancoradoiro, o da morte, irmã da noite e da razão, longe da Itália e da Questão romana da juventude, Antero nega o tempo, cessando-o, com um tiro "Pelas rugas da fronte que medita" (do soneto Jura), desesperada salvação poética da filosofia que buscava ("só os poemas parecem cada vez mais jovens e mais belos"), nela subsume a vida. "Morte, irmã coeterna da minha alma". Poesia e Filosofia cruzam-se no corredor do coração. Há seis anos que não escrevia poesia, mas publicara os melhores ensaios filosóficos.

53 Cf. Spinosa, Ética, IV, 39 scholium; (cf. "Despondency") 56, sch.

54 Fernando Catroga, Antero de Quental. História, socialismo, política, p. 118. 
tivo de Schelling - no exame de Hegel, abertura à história e a todas as formas de existência, lido na Introduction à la Philosophie d'Hégel (1855) ${ }^{55}$, de Vera, discípulo de Cousin em França, depois migrado em Inglaterra, por fim voltado a Itália em 1859, em plena unificação, à cátedra de história da filosofia em Milão e Nápoles.

Ao abonar, ínsita finalidade à História, objectivação da Ideia, Antero recorre à teleologia e à periodização das fases históricas que Vera melhor expusera a partir de Hegel (e Herder) em Introduzione alla filosofia della storia, caindo na espiral da história ideal e no acabamento do devir ${ }^{56}$. Com Vera, filiava na Scienza nuova de Vico, também por via de Michelet, em articulação, dir-se-á, com Ferrari, a precursora ideia das filosofias da história, espécie de teologia civil que se destinava a suprir no plano antropológico, ao qual só a imanente razão no fieri histórico pode aceder, o papel transcendente e providencial e suas traduções hierofânicas do passado e do devir. Noutro plano, embora sob influxo das teses martinianas, relevante é a mediação de Vera para relativizar etnocentrismo e o génio da raça que o positivismo republicano, mormente na versão de Teófilo, buscara em Schlegel e na mesologia como fundamento da nacionalidade ${ }^{57}$.

$\mathrm{O}$ explícito apoio a Vera na liça à transposição das leis da fatalidade animal para o mundo humano ${ }^{58}$ de D. Strauss e a ideação da liberdade, autoexigência hegeliana da verdade do espirito, melhor expostas pelo filósofo italiano ${ }^{59}$, certificam a leitura. Decisivo é o discurso sobre as teses do socialismo catedrático, na aspiração ética à juridificação do Estado, organismo social, e o repto do princípio progressivo de cidada-

\footnotetext{
${ }^{55} \mathrm{Ib}$., pp. 31-33.

${ }^{56}$ Cf. ib., pp. $51,67,108$

${ }^{57}$ Cf. ib., pp. 126-129.

${ }^{58}$ Antero de Quental, Cartas I, 1989, p. 255.

${ }^{59}$ Vera, int. a Hegel, Philosophie de l'esprit, t. II, Paris, Germer Baillière, 1869, pp.
} XLIX- LIX. 
nia, esteios para compreender o giro que Antero e Martins seguirão no seu ideário, articulando a fonte krausista com a secundarização proudhoniana da série política, a que não era estranho o ensinamento de Vera (na Introduzione), ao explicitar a organização moderna do Estado como garante da liberdade de todos os cidadãos e superação do atomismo, ordenando no topo as várias esferas que inteiram a sociedade em vista à prossecução dos seus fins ideais ${ }^{60}$.

Não será menor o influxo das leituras de Giuseppe Ferrari (1811-1876), estudioso de Vico (lido na fonte por Antero) e de Proudhon, sobre o qual deixou dispersos. Era crítico do panlogismo hegeliano e vivia desde 1838 exilado em França tendo voltado a Itália, como Vera, em 1859. Entende-se. Para Ferrari, autor da monumental História das revoluçōes de Itália (1856-1858, que o ilhéu possuía) e da Filosofia della rivoluzione (1850), a revolução política, a do Risorgimento, é indesligável da revolução social e da liberdade originada no princípio revolucionário, dinamismo histórico que nega heteronomia e providencialismo. Contra Cavour e o tacticismo de Mazzini, exige emancipar o estado italiano de qualquer tutela religiosa, sobretudo após a subida de Pio IX. E a tese do federalismo democrático encontrará eco no Antero iberista, na fase do idealismo construtivo. Da lição de Ferrari, ao articular a filosofia com a sua própria historicidade, arguindo o fecho do sistema hegeliano, Antero apreendera contudo o mérito da filosofia sintética, expressão superadora dos sistemas precedentes (que será mediada pela contingência, de Boutroux, e a conciliaçãa, de Fouillée $)^{61}$.

Ponte idealista do kantismo e hegelianismo ao positivismo, Ferrari parte do juizo, de Kant e Rosmini, arguindo o intelectualismo cartesiano, e conjuga a lição da scienza nuova, a imanente teleologia e a periodização, os corsi e ricorsi, na

${ }^{60}$ Fernando Catroga, Antero de Quental. História, socialismo, política, pp.163-164.

${ }^{61} \mathrm{Ib}$., p. 34. 
teoria dos três tempos do mundo, da espécie e do ser (teocrático, aristocrático e democrático ${ }^{62}$. Dela foi o mais relevante difusor em Itália, por meados do século XIX, com a lei dos três estados (teológico, metafísico, positivo) de Comte, que fora gizada sobre Vico, na determinação lógica da estrutura ${ }^{63}$ da historicidade. Ora, Ferrari vira em Vico o precursor da filosofia da história, matriz para desenvolvimento capital da historiosofia anteriana. Giuseppe Ferrari, em Vico et l'Italie, corrigia, em Vico, à semelhança do que fizera Vera, a circularidade do tempo. Para Antero, o tempo cíclico é inconciliável com a dialéctica do devir, mas não com a própria teoria dos três estados, naturalista, transcendente e imanente ${ }^{64}$. Relevância maior de Ferrari, no Essai sur le principe et les limites de la philosophie de l'histoire (1843), é o distingo entre demonstrativa história ideal (reconstrução retrospectiva filosófica, a partir do lugar hegeliano da verdade e do universal, que racionalmente aspira ao saber absoluto), e história positiva naquela subsumida, narrativa, empiria das antinomias do real ${ }^{65}$, fundo da concepção anteriana de história e devir. Em grande parte assenta no núcleo viquiano da cultura historiosófica destes autores italianos, sem obliterar a intensa relação com o Idealismo alemão, o proudhonismo, Michelet e o espiritualismo.

A gorra de Garibald SOBRE UMA DiEGESE DA CONSCIÊNCIA EM ANTERO

Decerto, Antero aspirou ao Garibaldi que não foi. Mas as armas revoltadas do poeta atiram "extraordinária imaginação especulativa" ${ }^{66}$, alvejando misérias e chagas do mundo

${ }^{62}$ Giambattista Vico, Ciência nova, $\$ \$ 36-39$, Lisboa, FCG, 2005, trad. Jorge Vaz de Carvalho, pp. 40-43.

${ }^{63} \mathrm{Ib} ., \$ 220 ; \$ 238$, pp. $135,140$.

${ }^{64}$ Cf. Fernando Catroga, Antero de Quental. História, socialismo, política, pp. 109111.

${ }^{65} \mathrm{Ib} ., 107-109$.

${ }^{66}$ Eduardo Lourenço, A noite intacta. (I)recuperável Antero, p. 101. 
mesmo. Como, ao contrário, o foram os moinhos hostis para Quixote (Cervantes, irmão diacrónico no Palácio da Ventura), os seus são operários de Lisboa (deserdados e não camponeses fabris) que missiona na revolução, cristianismo do mundo moderno que o cristianismo havia salinado, esquecido da própria antiga revolução. Às suas mãos, revolucionário ineficaz, ninguém sacrificou - nem como é uso para Salvar. $\mathrm{O}$ escrito da juventude, lendo Renan, "a alma da humanidade em cada homem e, na humanidade, a alma do mundo" ${ }^{67}$, não arruinara o denso sentido, mas a sua revolução, depois amadurecida na órbita íntima (ansich), identidade do espírito consigo mesmo, querendo volver aos outros, pensálos próxima irmandade. É revolução que a todos, e no mesmo tempo, não revolta nem revolve, porque no mesmo tempo não são irmãos, "Espectros dos meus próprios pensamentos / [...] quem sois vós, meus irmãos e meus algozes?" 68 .

"Optimista dentro do pessimismo", arguiu o sistema, que o ensinou a pensar, com Hegel, não só pelo credum panlógico, mas também por não o educar a sentir. Filosofia e saber racional, como Kant instara contra Platão, não irrompem de um corpo "em repouso" e sem paixões ${ }^{69}$. Não se aprende a sentir senão sendo, sentindo, sentir é criar (Fernando Pessoa). Da santidade ou virtù, pão semiótico não do espírito, mas da existência, Antero cria o paradigma secular. Em português, ninguém no século XIX com essa obsessiva insistência e intencionalidade ousara meditar o ethos, higiene búdica para "libertar a alma do ressentimento", não a superar bem e mal que no antípode (Ecce Homo) Nietzsche evangeliza, mas a "encarar sereno o abismo"70. Exegeses fundas (Lourenço, Catroga) negam que génio seja expediente retórico da mitifica-

${ }^{67}$ Antero de Quental, Obras completas, III, p. 16.

${ }^{68}$ Id., No turbilhão, Sonetos, p. 89.

${ }^{69}$ Cf. Hannah Arendt, Juger, Sur la philosophie politique de Kant, Paris, Seuil, 2003, pp. 50-51.

${ }^{70}$ Antero de Quental, Estoicismo, Sonetos, p. 88. 
ção anteriana (distante do mito em que o vertiam, inabilitou-o a virtù de nele se converter ${ }^{71}$ ), conduzida pela geração de 70 , Martins e Eça à cabeça, cuja mitografia negativa ${ }^{72}$ tinha em Teófilo o Mefistófeles e depois em Sardinha o anjo salvador. Ingenuum, o que se liberta e liberta o génio (genium, divindade criadora), convoca o pensamento sem mácula, enunciado irresolúvel pois é a originalidade do pecado que torna útil o pensar, alfaia teórica do ofício secularizado do pecador, pensador. Mas ao indeferir versões teológicas da sua filosofia, não inabilitou mediaçôes que exigiam a intuição teológica, da Theologie deutsche e do misticismo activo, como foi elucidado no sema da obra ${ }^{73}$, campo cuja complexidade analítica, como nenhum outro, suscita afinidades electivas e a sedução ética do ser.

Como Garibaldi no hábil senso, mas ao contrário dele em direcção à ipseidade, o obbedisco cingiu-se à voz que em si perscrutou, insorgimento, introspectiva consciência da irrenunciável ontologia, "facto íntimo" ", voz funda que se dirige a interrogar o ser (Ricoeur, Réflexion faite, 1995), espírito, lição hegeliana melhor lida em Vera, se o cnosce te ipsum "é o problema mais árduo que o oráculo de Delfos colocou à inteligência" e o espírito a si coloca ${ }^{75}$. $\mathrm{Na}$ "absoluta negatividade", "espírito de eterna negação" ${ }^{76}$, ser e saber são incindíveis, a mais concreta unidade é do mesmo modo a mais imediata e negativa ${ }^{77}$, isto é, só o pensamento, ideia e

${ }^{71}$ Cf., na polémica filosófica e religiosa de 1930-1931, Sílvio Lima que impugna a absurda tese da conversão católica do poeta. Ver Sílvio Lima, Notas críticas ao livro do sr. Cardeal Cerejeira "A Igreja e o pensamento contemporâneo", Obras Completas, I, Lisboa, FCG, 2002. A tese insinuara-se nos escritos de António Sardinha, "O verdadeiro Antero”, Ao princípio era o Verbo, Lisboa, Portugália, 1924, pp. 91-121.

${ }^{72}$ Contra a degenerescência, ver Silvio Lima, Obras completas, II, pp. 1465-1466.

${ }^{73}$ Cf. Fernando Catroga, Antero de Quental. História, socialismo, política, pp. 57-64.

${ }^{74}$ Joaquim de Carvalho, "A evolução espiritual de Antero", p. 671.

${ }^{75}$ Augusto Vera, int. a Hegel, Philosophie de l'esprit, t. I, 1867, p. XXI e passim.

${ }^{76}$ Antero de Quental, Estoicismo, Sonetos, p. 88.

${ }^{77}$ Augusto Vera, int. a Hegel, Philosophie de l'esprit, t. I, 1867, p. XLII. 
consciência, se "demonstra" a si próprio, revelação que coloca, desloca, o ser e a realidade das coisas no ápice de um fluxo "absoluto" e "eterno" que é pensamento ${ }^{78}$. O "drama do ser" é consciência bipartida. O princípio de identidade de Fichte (e de Hegel), fundado na igualdade do eu consigo mesmo, entrara em crise. Mas ao consciente devir do espírito, se Justiça é a auto-apreensão proudhoniana do justo, Antero quis dar a expressão simbólica, leia-se poiética, à sociedade dos justos ${ }^{79}$, difícil passagem da inconsciência das coisas à consciência do $\operatorname{ser}^{80}$.

Semibreves átonas à escala do tempo cósmico, os seres acossam o ruído apógrafo, na ficção (u-topos) da eternidade. No lanço da escada monadológica de acesso à liberdade, de si nos outros, não sobre outros, da alteridade como espinosiana consciência de si, Antero abraçou na filosofia a inteligência teorética e o repto metafísico da condição humana a partir da contingência empírica do existir, isto é, da condição históri$\mathrm{ca}^{81}$. A estóica genealogia anteriana da sagesse, traçada por Unamuno em Santo Agostinho, Rousseau, Leopardi, Amiel, Kleist, Kierkegaard, na filosofia e no sentimento trágico da vida $^{82}$, será esclarecedora se, a par do Hino à manhãa, abranger nas esparsas clareiras de Nietzsche os penitentes do espirito que nascem entre os poetas (Assim falava Zaratustra, II, "Dos poetas"). Essa procedência radica do lugar. Antero impediu a contemplação da história (ou da filosofia) a partir de lado nenhum. Joaquim de Carvalho lera, à luz do método genético-evolutivo, a sua filosofia (e poesia) em função da onticidade inapreensível fora da historicidade. Renunciando ao hedonismo lógico-processual e à tecnologia autista do discurso,

${ }^{78}$ Cf. ib., p. CXII.

${ }^{79}$ Eduardo Lourenço, A noite intacta. (I)recuperável Antero, pp. 33-34.

${ }^{80}$ Fernando Catroga, Antero de Quental. História, socialismo, política, pp. 56-57.

${ }^{81}$ Paul Ricoeur, Temps et récit, III, Le temps raconté, Paris, Seuil, 1985, pp. 301-302.

${ }^{82}$ Miguel de Unamuno, Del Sentimiento trágico de la vida, Buenos Aires, EspasaCalpe, 1941, $4 .^{\text {a }}$ ed., pp. 20-21. 
métrica do convencimento, a sua sabedoria é a metafísica pergunta pelo ser num tempo que mais anulava essa pergunta. O anseio à novação social e ética do mundo ("Não sei que mão deitou uma semente / escura mas divina, a do Futuro" ${ }^{83}$ ) seria intelecção de que os "futuros não realizados são apenas ramos do passado", escrevia Calvino, "ramos secos" ${ }^{84}$ ?

Instante aporia foi essa que traduziu, porquanto anterior à matança que, na perspectiva do lugar e da experiência humana, representou o século XX. Ainda o escuta em Cativos lúgubres, "Entre sombras, ao longe, vagamente / morrem as vozes na extensão saudosa" 85 e nos Pobres ${ }^{86}$,

que ainda a luz que vê um pobre cego

luzir-lhe em sua noite, e a fantasia

em mundos ideais lhe anda acendendo...

Todavia, não recitou o hodierno e funcional phantasieren dos campos-de-concentração de raças, credos. Agora, velhos, refugiados, inadaptados, crianças, pobres. Asilo, guerra, jogo autofágico ${ }^{87}$, exílio algum legitima isolar o sendo na ilha do ser. Em 1889, lendo Hegel nas Tendências gerais da Filosofia, Antero reavalia a dialéctica metafísica, "é atreita a esquecer que os indivíduos não são abstracções, simples determinaçóes lógicas de uma ideia, mas seres reais, autónomos, cujo princípio de acção reside nas profundezas da própria sua natureza”. Na idade dos profetas (Hegel, Proudhon, Comte, Marx), o pequeno Lassalle refuta as saídas de emergência da razão apodíctica, transmudadas à entrada do século XX na razão apocalíptica do terror. Denuncia no fieri filosófico a trágica desrazão (essa seria a sua versão da Filosofia da miséria) se o pensamento ilude ou gera a anamnese das "lutas secretas

\footnotetext{
${ }^{83}$ Antero de Quental, «Secol' si rinuova» IX, Odes modernas, p. 106.

${ }^{84}$ Italo Calvino, As cidades invisiveis, s. 1., s. ed., 2009, p. 34.

${ }^{85}$ Antero de Quental, Sonetos, p. 257.

${ }^{86}$ Antero de Quental, Odes modernas, p. 162.

${ }^{87}$ Cf. Umberto Eco, Cinco escritos morais, Lisboa, Difel, 1998, p. 23.
} 
da virtude e dos seus dolorosos triunfos". Mas, com Platão, na exegese da interioridade e da unidade "mística", superior consciência de si (Hegel, Enciclopédia [...], 1817) - dos anos 60 , sob a gorra militar de Garibaldi ou na missão revolucionária da poesia, à encenação pacífica da revolução em 70 , no desafio da história, útil chão para um espírito justo cultivar -, Antero, "alucinado da metafísica" ${ }^{88}$, navegou pelo cabo do tormento que foi a sua vida na senda da ética autolibertação que per-seguiu. Esse combate ético, uma hermenêutica do tempo não deixará de interrogar se é futuro irrealizado.

${ }^{88}$ Oliveira Martins a Eça de Queirós, Correspondência, Lisboa, Guimarães, 1926, p. 161. 